\title{
EDUKASI PENCEGAHAN PENULARAN TBC PADA KELOMPOK WANITA USIA SUBUR DI RPTRA BAMBU PETUNG DAN PAYUNG TUNAS TERATAI DI JAKARTA TIMUR PADA TAHUN 2019
}

\author{
Cicilia Windiyaningsih ${ }^{1}$, Yeni Sulistyowati ${ }^{2}$, Yeni Ariestanti ${ }^{3}$, \\ Tiwi Nurhastuti ${ }^{4}$,Erik Sapta Yanuar ${ }^{5}$ \\ Pascasarjana Kesehatan Masyarakat, Universitas Respati Indonesia ${ }^{1,3}$ \\ Fakultas Teknologi Informasi, Universitas Respati Indonesia ${ }^{4}$ \\ Fakultas Manajemen dan Bisnis, Universitas Respati Indonesia ${ }^{5}$ \\ Jl Bambu Apus I no. 3 Cipayung, Jakarta Timur 13890 \\ Email : ${ }^{1}$ sisilwindi@gmail.com, ${ }^{2}$ yeny.sulistyowati@urindo.ac.id, ${ }^{3}$ yariestanti@urindo.ac.id, \\ ${ }^{4}$ tiwi@urindo.ac.id, ${ }^{5}$ erik@urindo.ac.id
}

\begin{abstract}
Abstrak
Di seluruh dunia Tuberculosis masih masalah kesehatan yang utama. Koinfeksi TB + HIV dan TB resisten obat nenjadi beban di pemerintah maupun di masyarakat. Tujuan pemberdayaan ini adalah membuktikan edukasi akan meningkatan pengetahuan wanita usia subur dalam pencegahan penularan Tuberkulosis sebelum dan sesudah diberikan materi pencegahan penularan tuberculosis. Sampel untuk wanita usia subur di Ruang Publik Terpadu Ramah Anak (RPTRA) Bambu Petung sejumlah dan Payung Tunas Teratai sebanyak 139 Wanita Usia Subur (WUS). WUS secara sukarela yang mau melakukan pre, post dan visitasi tes. Kuesioner yang dipergunakan sesuai standar Kementrian Kesehatan Tahun 2019. Analisis secara deskriptif dan analitik dengan Spearman Corelation:. Hasil Pengetahuan berhubungan bermakna nilai pretes dan post tes setelah dilakukan edukasi pencegahan penularan Tuberculosis pada WUS dengan proposi yg menjawab salah pada pre tes 40WUS (28.8\%) sedangkan post tes yang salah 10 WUS (7.2\%) artinya ada penurunan proporsi yang menjawab pertanyaan tidak benar. Proporsi yang menjawab benar dari $70 \%$ menjadi $92.8 \%$ artinya ada peningkatan yang menjawab pertanyaan benar sejumlah $22.8 \%$. Hasil analisis statistik perbedaan penurunan dan kenaikan tersebut bermakna dengan nilai p 0.006, OR 6.788, 95\%CI 1.659-27.779. Kesimpulan edukasi meningkatan pengetahuan WUS tentang pencegahan penularan Tuberculosis.

Kata Kunci : Edukasi, Pengetahuan Pencegahan Penularan TBC, WUS
\end{abstract}

\begin{abstract}
Around the world Tuberculosis is still a major health problem. Increasing cases of TB+ $H I V$ coinfection and drug resistant $T B$ their are a burden on the government and the community. The purpose of this empowerment is to prove that education will increase the knowledge of women of childbearing in the prevention of tuberculosis transmission before and after the material was given to prevent transmission of tuberculosis. Samples women of childbearing in the Child Friendly Integrated Public Space (RPTRA) of Bambu Petung and 139 Lotus Tunas Umbrellas for Women of Fertile Age (WUS). WUS voluntarily wants to do pre, post and visit test. The questionnaire was used according to the Ministry of Health's 2019 standards. Descriptive and analytic analysis with Spearman Correlation: The results have a significant
\end{abstract}


relationship between the pretest and posttest values after the education of prevention of Tuberculosis prevention in WUS with the proportion that answers incorrectly in the pretest 40WUS (28.8\%) while the wrong the posttest 10 WUS (7.2\%) means there is a decrease in the proportion that answers incorrect questions. The proportion of those who answered correctly from $70 \%$ to $92.8 \%$ means that there was an increase in those who answered the questions correctly by $22.8 \%$. The results of the statistical analysis of the difference in the decrease and increase were significant with p values 0.006, OR 6.788, 95\% CI 1.659-27.779. Educational conclusions increase knowledge of WUS about preventing tuberculosis transmission.

Keywords: Education, TBC Knowledge, Productive Age Women

\section{Latar Belakang Masalah}

Di seluruh dunia Tuberculosis masih masalah kesehatan yang utama. Koinfeksi TB + HIV dan TB resisten obat nenjadi beban di pemerintah maupun di masyarakat. Pada tahun 2013, diperkirakan insiden tuberkulosis secara global mencapai 9 juta $^{1}$. Jumlah penderita TB paru di Indonesia terus meningkat, terdapat 460.000 kasus baru TB dengan jumlah kematian sebesar 62.246 orang $^{2}$. Di dunia kematian karena TB banyak Secara ekonomi dampak TBC lebih bermakna secara ekonomi dan reproduksi dan pada anak dan famili lainnya. Faktor presdisposi: pengetahuan, pendidikan, umur, sikap, kepercayaan, norma sosial, persepsi yang dimiliki oleh WUS dapat terkait dengan program pengendalian TBC yang sudah dilaksanakan. Hal ini dimaksudkan agar semua pihak yang terlibat memiliki pemahaman yang benar terkait upayaupaya pencegahan penularan TBC tersebut. Wanita Usia Subur atau ibu -ibu menjadi sampel dalam edukasi ini sebab merupakan pengunjung terbanyak dan teraktif dalam upaya-upaya pencegahan atau pemeliharaan kesehatan di masyarakat. Keuntungan yang dapat dimanfaatkan aktifitas ini adalah: peserta mempunyai pendapat, memahami, dan menjelaskan serta menerapkan pencegahan penularan Tuberculosis. Tujuan penelitian ini adalah untuk membuktikan edukasi pengetahuan,sikap dan perilaku tentang pencegahan penularan Tuberkulosis sebelum diberikan materi pencegahan penularan Tuberculosis dibandingkan sesudah diberikan materi dan simulasi terjadi peningkatan nilai rerata pengetahuan, sikap dan perilaku.

\section{Masalah}

Adapun permasalahan yang ada dapat diidentifikasikan dalam tiga Kelompok besar, yaitu: masalah terkait pengetahuan, sikap dan perilaku wanita usia subur dalam Pencegahan TBC, serta perlunya penguatan RPTRA Payung Tunas Teratai dan Bambu Petung. Oleh karena itu masalah program pengabdian ini dirumuskan menjadi dua:

1. Pertama apakah pengetahuan, sikap dan perilaku yang harus dimiliki oleh Wanita Usia Subur terkait dengan upaya pencegahan TBC.

2. Kedua bagaimanakah upaya yang bisa dilakukan oleh kedua RPTRA tersebut untuk menjaga keberlangsungan program yang direncanakan?

\section{Metode}

Peserta edukasi 146 orang yang bersedia ikut PKM Edukasi dan disetujui bapak RW ke RT dan nama-namanya diinformasikan kepada Koordinator RPTRA Bambu Petung dan Payung Tunas Teratai. Sebelumnya dilakukan identifikasi pengetahuan tentang pencegahan penularan TB Peserta edukasi 70 orang yang bersedia ikut PKM Edukasi dan disetujui bapak RW ke RT dan nama-namanya diinformasikan kepada Koordinator RPTRA Bambu Petung dan Payung 
Tunas Teratai $\mathrm{C}$ dengan pre tes 70 orang. Kemudian dilanjutkan dengan penyampaian materi pencegahan penularan TBC dengan ceramah interaktif dan tanya jawab, dan diberikan draft buku oleh narasumber. Setelah itu dilanjutkan pembagian kelompok ada 7 kelompok per RW RPTRA Bambu Petung untuk simulasi dan praktik mevisualisasikan gambar pencegahan penularan Tuberkulosis pada tanggal 25-26 juli Tahun 2019 dari jam 08.00-12 WIB terus dilanjutkan Post Tes hanya 52 orang. Untuk RPTRA Payung Tunas Teratai tahapan pelaksanaannya PKM sama seperti di Bambu Petung pada tanggal 6-7 Agustus tahun 2019. Pukul 08.00-12.00. Pre tes 94 orang dan post tes 94 orang. Soal Pertanyaan pengetahuan pencegahan penularan Tuberkulosis pertanyaan ada di dalam buku saku dan menggunakan acuan standar pertanyaan tentang pencegahan penularan TBC dari Kementrian Kesehatan Republik Indonesia. Hasil pre dan post tes yang dilakukan analisis RPTRA Bambu Petung dan Payung Tunas Teratai sejumlah 52+94 =146 orang, analisisnya secara deskriptif dan analitik dengan uji chi square dengan Spearman Correlation. Selain itu hasil praktik visualisasi gambar pencegahan penularan TBC juga dilombakan. Pemenangnya yang diberikan hadiah gambar terbaik 1,2 dan 3. Hasil PKM juga dipublikasikan di majalah Tribun dan juga youtube, pembicara seminar dan jurnal PKM.

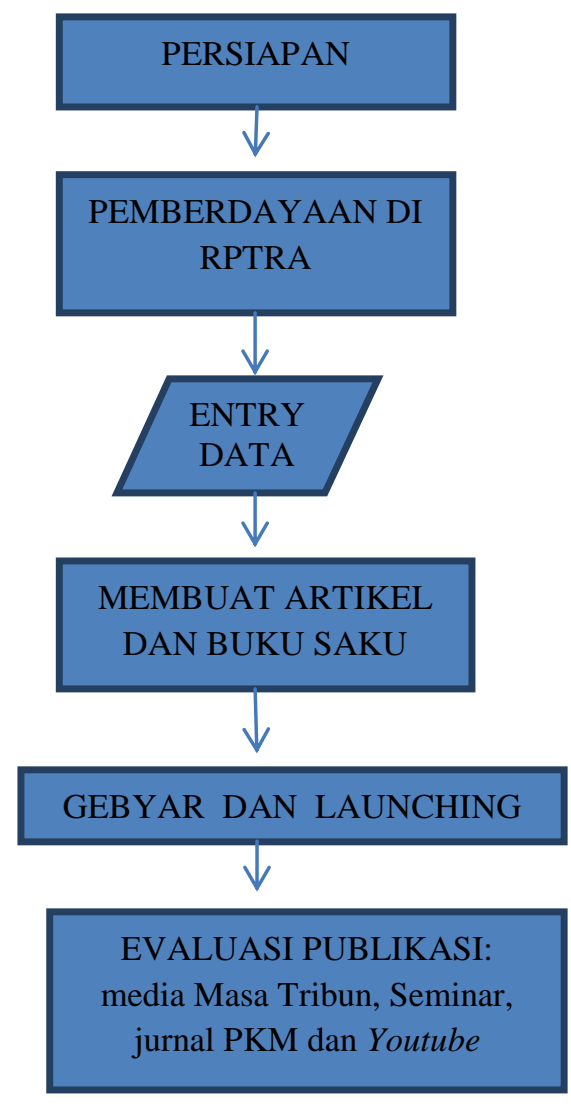

Gambar 1. Diagram Alur Kegiatan

Adapun kegiatan yang dilaksanakan adalah meliputi:

1. Melakukan Persiapan pelaksanaan pemberdayaan kelompok wanita usia subur di RPTRA Bambu Petung dan Bambu Apus dalam Pencegahan Penularan Tuberkulosis dengan membuat surat izin, pertemuan dengan bapak lurah, kepala Puskesmas, dan koordinator di RPTRA Bambu Petung dan Bambu Apus. 
2. Melaksanakan pemberdayaan kelompok wanita usia subur di RPTRA Bambu Petung dan Bambu Apus Dalam Pencegahan Penularan Tuberkulosis pada tanggal 25-26 Juli di RPTRA Bambu Petung; Tanggal 6-7 Agustus di RPTRA Payung Tunas Teratai dengan Pre dan Post Test dilakukan saat pemberdayaan pada saat awal dan akhir pemberdayaan

3. Melakukan entry data, coding, editing, analisis deskriptif dan analitik, membuat laporan pre tes dan post test

4. Membuat rancangan artikel, dan buku saku hasil lomba visualisasi gambar pencegahan penularan TBC.

5. Gebyar dan Launching Buku Saku Pencegahan Penularan TBC serta evaluasi.

\section{Hasil Dan Pembahasan}

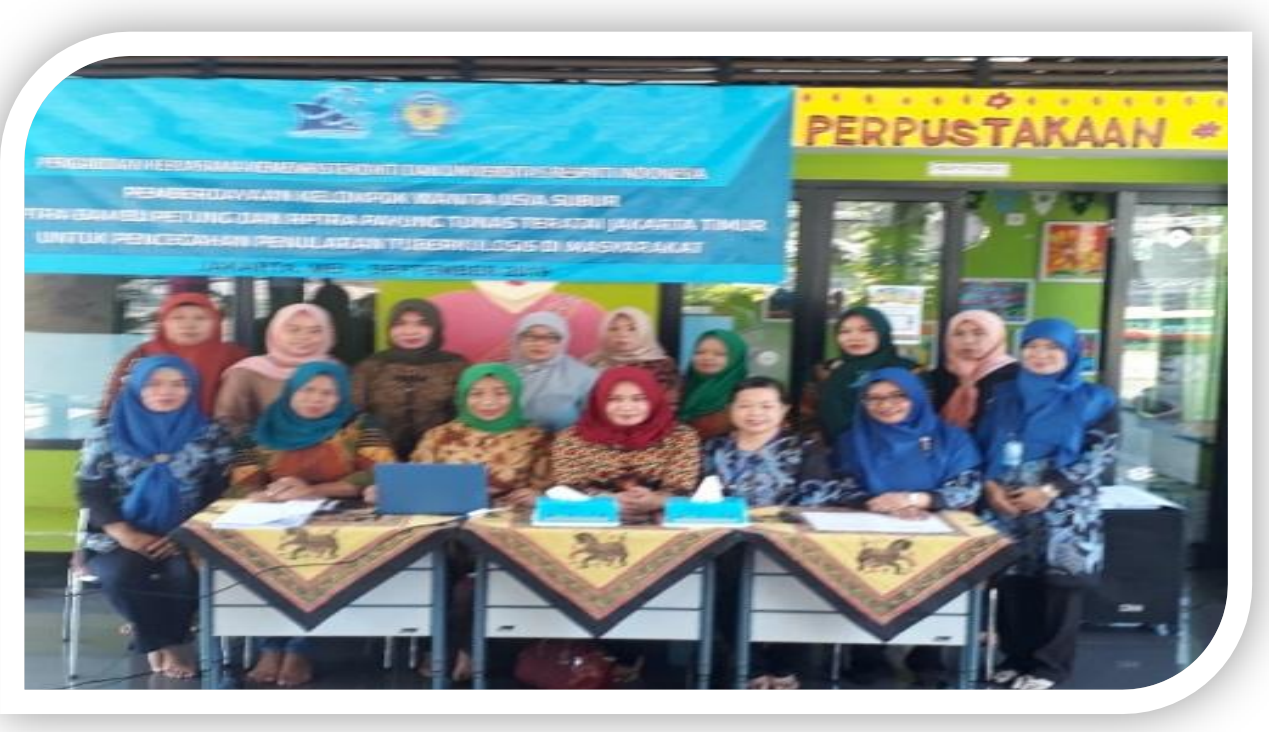

Gambar 2 Tim PKM Bersama Ibu Lurah dan pengurus RPTRA Bambu Petung Dan Payung Tunas Teratai, Kecamatan Cipayung, Jakarta Timur.

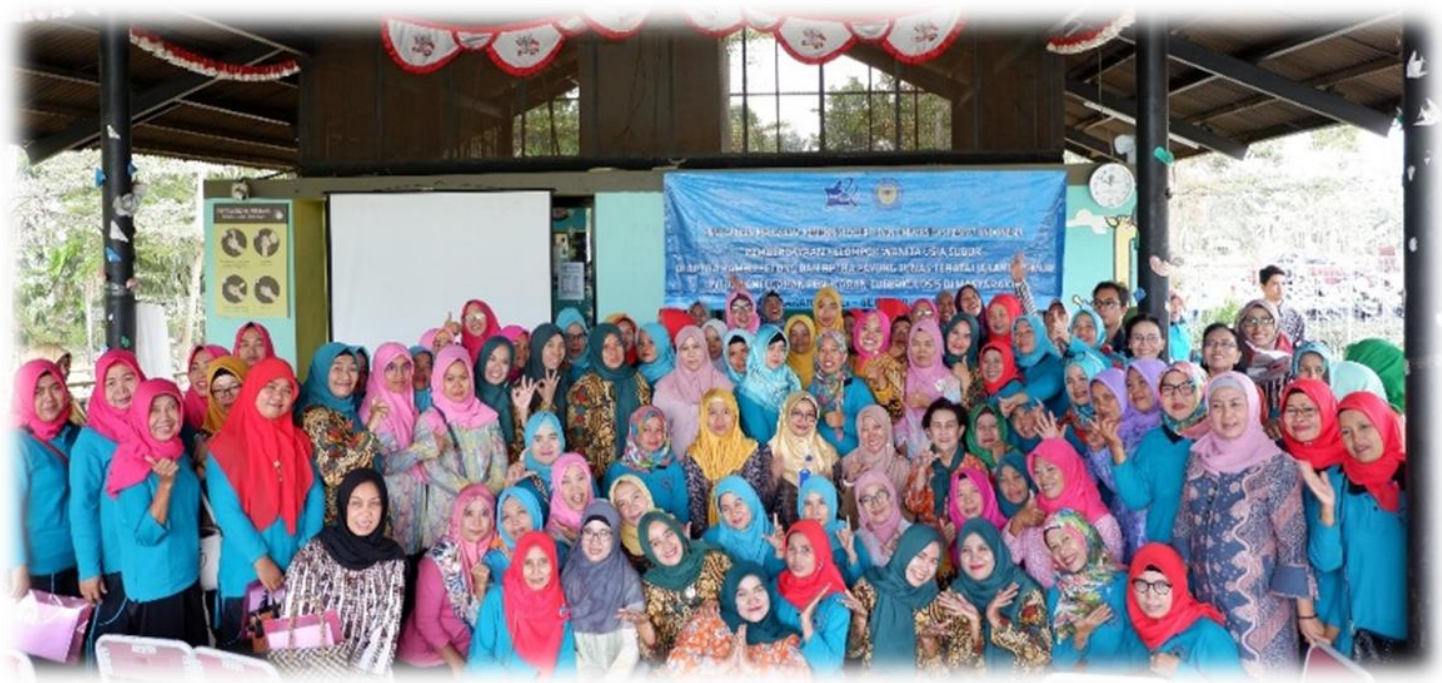

Gambar 3. Foto Edukasi di RPTRA Bambu Petung 


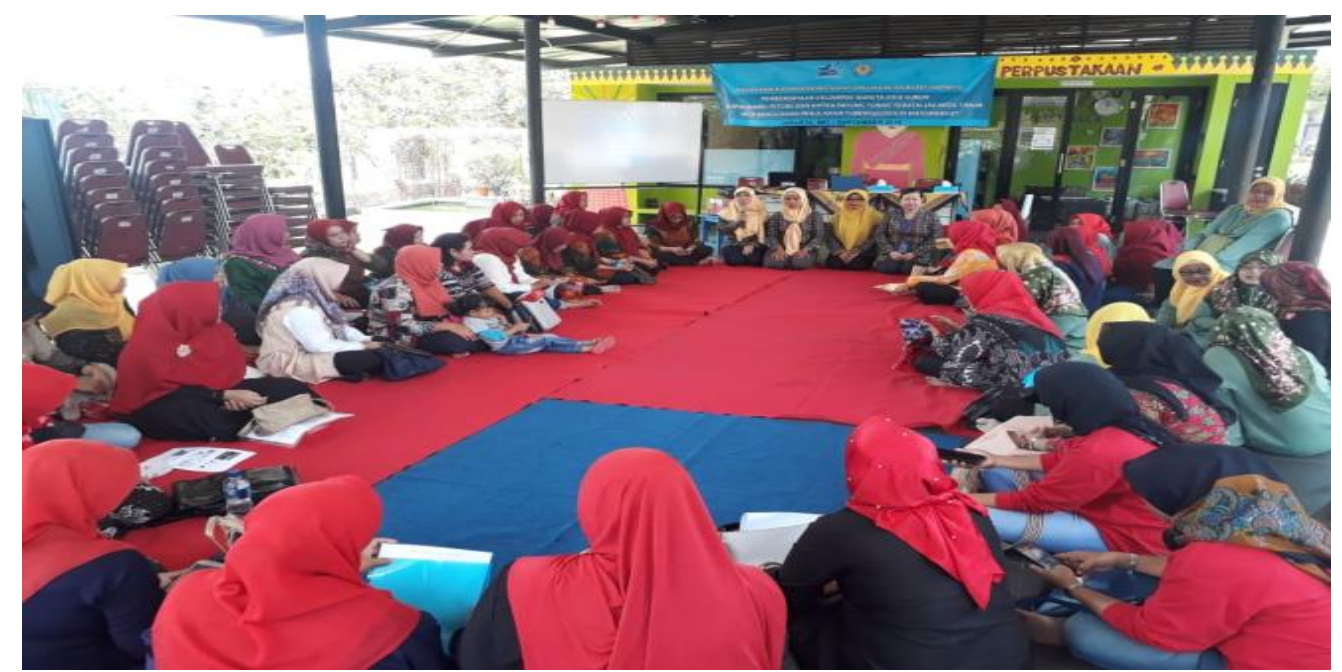

Gambar 4. Edukasi di RPTRA Payung Tunas Teratai
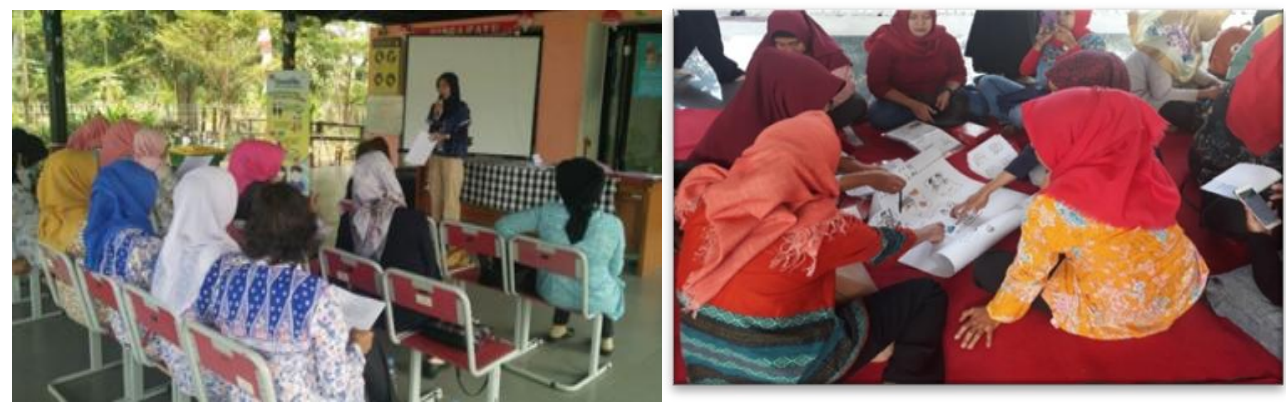

Gambar 5. Kelompok Simulasi dan Praktik Menggambar Pencegahan Penularan TBC.

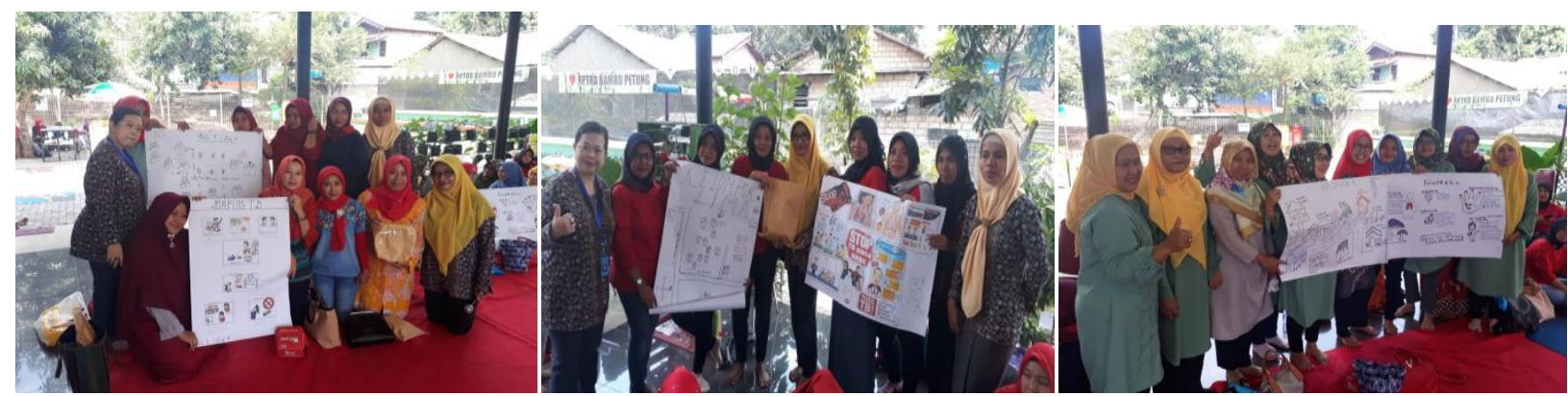

Gambar 6. Gambar hasil Simulasi dan Praktik Menggambar Pencegahan Penularan TBC. 
Tabel 1. Analisis Deskriptif Nilai Pretes dan Postes Pengetahuan Pencegahan Penularan TB WUS di RPTRA Bambu Petung \& Payung Tunas Teratai Tahun 2019

\begin{tabular}{l|r|r} 
& Pretotal & POSTOTAL \\
\hline $\mathrm{N}$ & 139 & 139 \\
\hline Mean & 12.75 & 13.94 \\
\hline Std. Error of Mean & .180 & .125 \\
\hline Median & 13.00 & 14.00 \\
\hline Mode & 13 & 14 \\
\hline Std. Deviation & 2.127 & 1.468 \\
\hline Variance & 4.523 & 2.156 \\
\hline Skewness & -.683 & -1.111 \\
\hline Std. Error of Skewness & .206 & .206 \\
\hline Range & 10 & 7 \\
\hline Minimum & 6 & 9 \\
\hline Maximum & 16 & 16 \\
\hline Sum & 1772 & 1938 \\
\hline
\end{tabular}

Berdasarkan hasil analisis deskriptif rerata nilai pretes 12.75 setelah post tes menjadi 13.94 terjadi peningkatan sebesar $9.33 \%$. Nilai median, mode sama meningkat satu digit, standar deviasi turun sejumlah 0.659 menjadi lebih kecil.Nilai minimum juga meningkat sebesar 50\%, nilai maximum tetap 16 artinya ada yang betul semuanya menjawab soal pengetahuan pencegahan penularan TBC.

Tabel 2. Hasil Analisis Hubungan Karakteristik Dengan Hasil Post Test Pengetahuan

\begin{tabular}{|c|c|c|c|c|c|c|c|}
\hline No & Variable & $\begin{array}{l}\text { Post } \\
\text { Test } \\
\text { Not } \\
\text { Good } \\
\end{array}$ & $\begin{array}{l}\text { Value } \\
\text { Good }\end{array}$ & $\begin{array}{l}\mathbf{P} \\
\text { value } \\
\end{array}$ & OR & $\begin{array}{l}95 \% \mathrm{CI} \\
\text { Lower }\end{array}$ & Upper \\
\hline 1 & $\begin{array}{l}\text { Age } \\
\geq 50 \text { years } \\
<50 \text { years }\end{array}$ & $\begin{array}{l}2 \\
(7.1 \%) \\
8 \\
97.2 \%)\end{array}$ & $\begin{array}{l}26 \\
(92.9 \%)\end{array}$ & 1.000 & 0.990 & 0.198 & 4.945 \\
\hline 2 & $\begin{array}{l}\text { Education } \\
\text { Low } \\
\text { High }\end{array}$ & $\begin{array}{l}10 \\
(7.7 \%) \\
0 \\
(0.0 \%) \\
\end{array}$ & $\begin{array}{l}120(92.3 \\
9 \\
(100 \%)\end{array}$ & 0.628 & 0.923 & 0.878 & 0.970 \\
\hline 3 & $\begin{array}{l}\text { Occupation } \\
\text { Not } \\
\text { working } \\
\text { Working } \\
\end{array}$ & $\begin{array}{l}10 \\
(7.4 \%) \\
0 \\
(0.0 \%)\end{array}$ & $\begin{array}{l}125(92.6 \\
4 \\
(100 \%)\end{array}$ & \%) & 0.926 & 0.883 & 0.971 \\
\hline 4 & $\begin{array}{l}\text { Income } \\
\leq 2.117,713 \\
>2.117,713\end{array}$ & $\begin{array}{l}2 \\
(10.5) \\
8 \\
(6.7 \%)\end{array}$ & $\begin{array}{l}17 \\
(89.5) \\
112(93.3\end{array}$ & 0.627 & 1.647 & 0.322 & 8.417 \\
\hline
\end{tabular}


Berdasarkan Tabel 1 tentang hasil analisis hubungan karakteristik dengan hasil postes pengetahuan pencegahan penularan TBC, terbukti 4 karakteristik tersebut tidak ada hubungan bermakna dengan nilai posttest setelah diberikan edukasi .

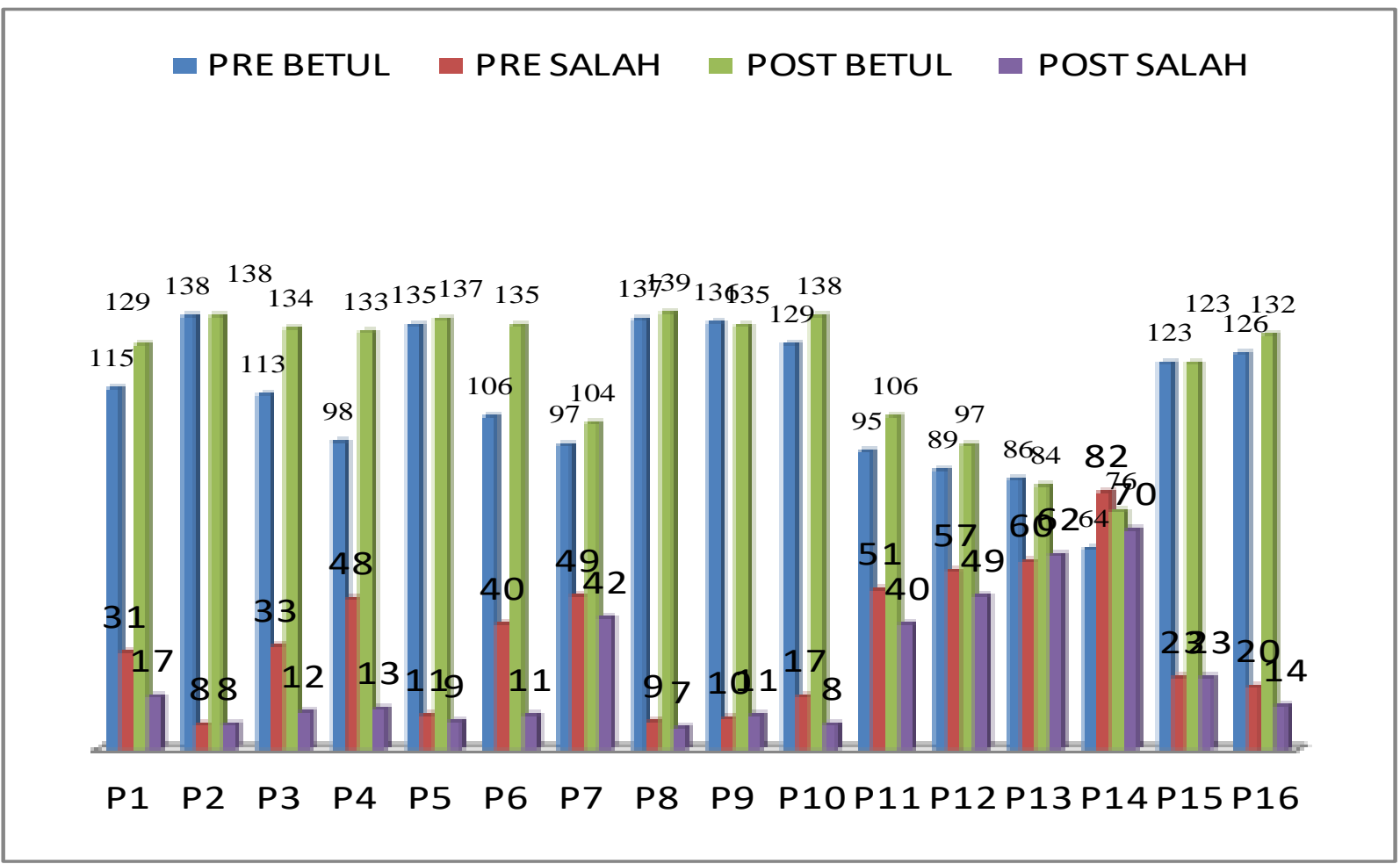

Gambar 7. Grafik hasil edukasi pengetahuan pencegahan penularan TBC Pre dan Pos Tes WUS RPTRA Bambu Petung dan Payung Tunas Teratai Tahun 2019.

Tabel 3. Hasil analisis nilai pre tes dan post tes setelah edukasi pencegahan PENULARAN TB WUS RPTRA Payung Tunas Teratai dan Bambu Petung

\begin{tabular}{|c|c|c|c|c|c|c|}
\hline \multirow[t]{2}{*}{ Variable } & \multirow{2}{*}{$\begin{array}{l}\text { Post } \\
\text { Test } \\
\text { Not } \\
\text { Good } \\
\end{array}$} & \multirow{2}{*}{$\begin{array}{l}\text { Value } \\
\text { Good } \\
\end{array}$} & \multirow{2}{*}{$\begin{array}{l}P \\
\text { value } \\
\end{array}$} & \multirow[t]{2}{*}{ OR } & \multicolumn{2}{|l|}{$95 \% \mathrm{CI}$} \\
\hline & & & & & Lower & Upper \\
\hline $\begin{array}{l}\text { Pre Test } \\
\text { Not } \\
\text { Good } \\
\text { Good }\end{array}$ & $\begin{array}{l}7 \\
(17.5 \%) \\
3(3 \%) \\
\end{array}$ & $\begin{array}{l}33 \\
(82.5 \%) \\
96 \\
(97 \%) \\
\end{array}$ & 0.006 & $6 / 788$ & 1.659 & 27.779 \\
\hline
\end{tabular}

Berdasarkan Tabel 3 hasil temuan antara nilai pre tes dibandingkan post tes pengetahuan tentang pencegahan penularan TBC ternyata ada hubungan bermakna, artinya pemberian edukasi berhasil meningkatkan pengetahuan WUS hampir tujuh kali lipat dibandingkan sebelum diberikan edukasi. Berdasarkan grafik 1 nilai pengetahuan pre tes pertanyaan yang banyak salah menjawabnya adalah : pertanyaan nomor P14 sebanyak 64 orang (46\%) tentang apakah harus melanjutkan pengobatan sampai selesai walaupun hasil pemeriksaan dahak anda sudah negative; 
nomor P13 sejumlah 54 orang (38.8\%) tentang berapa lama pengobatan TBC yang sudah kebal terhadap obat TBC yang dianjurkan; nomor P12 sejumlah 51 orang (36.7\%) tentang mengapa penyakit TBC yang kebal obat lebih sulit disembuhkan daripada TBC biasa; nomor P11 sejumlah 45 orang $(32.4 \%)$ tentang tentang menurut anda penyakit paru yang dapat kambuh kembali disebut apa; nomor P6 dan no.P7 sejumlah masing -masing 43 orang (30.9\%) tentang menurut anda penyakit TBC dapat deegah dengan imunisasi apa, menurut anda penyakit TBc dapat disembuhkan dengan pengobatan apa; nomor P3 sejumlah 42 orang (30.2\%) tentang menurut anda penyakit TBC Paru dapat menular kepada orang lain karena apa?; nomor P5 sejumlah 34 orang (24.5\%) tentang menurt anda acara terbaik untuk menghindari penularan TBC terhadap orang lain;nomor P2 sejumlah 27 orang (19.4\%) tentang menurut anda bagaimana tanda-tanda/gejala penyakit TBC.

Nilai pengetahuan post tes pertanyaan yang banyak salah menjawabnya adalah: pertanyaan nomor 14 sejumlah 63orang (45.3\%) tentang apakah harus melanjutkan Pengobatan sampai selesai walaupun hasil pemeriksaan dahak anda sudah negatif; 13 sejumlah 55 orang (39.5\%) tentang berapa lama pengobatan TBC yang sudah kebal terhadap obat TBC yang dianjurkan; 12 sejumlah 42 orang (30.2\%) tentang mengapa penyakit TBC yang kebal obat lebih sulit disembuhkan daripada TBC biasa; 7 sejumlah 35 orang (25.1\%) tentang menrut anda penyakit TBC dapat disembuhkan dengan pengobatan apa,11 sejumlah 33 orang (23.7\%) tentang menurut anda penyakit paru yang dapat kambuh kembali disebut apa.

Kendala PKM ini untuk RPTRA Bambu Petung identifikasi pengetahuan pre tes 70 orang, namun post tes hanya 52 orang, karena tidak hadir lagi pada hari ke dua, menurut informasi ada acara lain. Namun berdasakan pengalaman ini untuk RPTRA Payung tunas Teratai tidak ada kendala dari 94 yang hadir pada hari pertama hari kedua tetap hair untuk ikut serta pos tes. Pada waktu penyelenggaraan secara umum Bapak Rt,RW, Lurah , Kepala Puskesmas, Ibu Ketua PKK, Kader, Pengawas Mnum Obat TBC merasa senang telah dibantu model edukasi yang komprehensif (diberikan ceramah, materi buku saku, dan praktik menggambar berkelompok per RW tentang pencegahan penularan TBC), dan edukasi ini kepada bukan penderita TBC namun masyarakat umum khususnya wanita usia subur atau ibu-ibu, ada juga ternyata wanita lanjut usia di lingkungan Kelurahan Cipayung dan Bambu Apus ikut edukasi juga.

Edukasi kepada WUS di RPTRA Bambu Petung dan Payung Tunas Teratai nilai pretes dibandingkan nilai post tes berhubungan bermakna dengan peningkatan pengetahuan sebesar 9.33\% , penelitian lain tidak mengevaluasi satu bulan kemudian setelah edukasi namun hasilnya sama dengan penelitian Chindo Ibrahim Bisallah (2018), hasil evaluasi 3 bulan, 6 bulan dan 9 bulan terjadi peningkatan pengetahuan, sikap dan perilaku dan semua bermakna nilai $\mathrm{p}<0.05$. Studi ini tidak berbeda dengan studi Chindo dkk. Meskipun subyeknya bukan penderita TB melainkan semua wanita usia subur dan sehat tidak menderita TB. Penelitian Yuwana Hesti Ummami, Abi Muhlisin, Dian Nur W.pada Tahun 2016 di Puskesmas Simo, Surakarta, Jawa tengah juga bermakna nilai pengetahuan pre tes dibandingkan post tes terhadap penderita TBC. Penelitian Dwi Ratnasari Yuhantoro Budi Handoyo Sakti Tahun 2015 di Di Puskesmas Curug, Pakuhaji, Pasar Kemis, Gembong dan Balaraja, Tangerang, Banten pada Tahun 1999 pernah dilakukan studi oleh Bambang Sukana, Herryantos, dan Supraptini 94.05\% penderita tahu tentang tanda dan gejala TB, 75\% lebih penderita tidak tahu penyebab TB paru, Pengetahuan mengenai cara penularan TB paru $78.6 \%$, sebagian besar penderita tidak mengetahuinya $(88,09 \%)$. Pengetahuan tentang hal yang mempengaruhi penularan TB paru yang terbanyak tidak tahu $(53,57 \%)$, sedangkan pengetahuan tentang hal-hal yang membantu pengobatan sebagian 
besar sudah tahu $(60,05 \%)$. Pengetahuan penderita setelah dilakukan penyuluhan hampir sebagian besar penderita mengetahui tanda dan gejala TB paru $(92,9 \%)$, demikian pula dengan penyebab TB paru hampir seluruhnya mengetahui (90,5\%), hal-hal yang membantu pengobatan sebagian besar mengetahui $(88,01 \%)$, Lailatul Maghfiroh, Antonius Nugraha Widhi Pratama, Ema Rachmawati Puskesmas Kaliwates, Patrang, dan Mayang, Madura, Jawa Timur ,Tahun 2017 Berdasarkan penelitian yang telah dilakukan, responden penderita TB mayoritas berjenis kelamin laki-laki yaitu sebesar 51,8\% dengan kisaran usia paling banyak 36-45 tahun sebesar 29,7\%. Berdasarkan pendidikan terakhir yang ditempuh, mayoritas responden penderita TB adalah tamatan SD yaitu sebesar 44,4\%, sedangkan berdasarkan pekerjaannya,responden paling banyak bekerja sebagai ibu rumah tangga yaitu sebesar 33,3\%. Penderita TB yang menjadi responden dalam penelitian ini mayoritas tidak memiliki riwayat penyakit lain $(59,3 \%)$ dan beberapa di antaranya memiliki riwayat penyakit lain seperti diabetes $(29,7 \%)$ dan hipertensi (11\%). Dalam penelitian ini, responden kelompok PMO mayoritas berjenis kelamin perempuan yaitu 74\%, dengan kisaran usia paling banyak 26-35 tahun sebesar 47,9\%. Mayoritas responden PMO memiliki pendidikan terakhir SMA, yaitu sebesar 39,2\%. Berdasarkan pekerjaannya, mayoritas responden PMO juga bekerja sebagai ibu rumah tangga, yaitu sebesar 39,2\%. dapat dilihat perbedaan jumlah tingkat pengetahuan penderita TB dan PMO antara sebelum dan sesudah pemberian edukasi menggunakan buku saku bergambar dan berbahasa Madura. Sebelum diberikan edukasi, jumlah responden paling banyak memiliki tingkat pengetahuan sedang dan setelah diberikan edukasi, mayoritas tingkat pengetahuan responden menjadi tinggi. Faktorfaktor yang mempengaruhi pendidikan kesehatan adalah materi yang diberikan, media edukasi, serta materi yang disampaikan cukup menarik dilihat dari antusias responden sehingga responden lebih mudah menerima informasi yang disampaikan. Media edukasi berupa buku saku yang digunakan dalam penelitian ini berisi tentang informasi seputar TB yang dilengkapi dengan gambar dan disampaikan dalam bahasa Madura dan bahasa Indonesia. Buku saku ini dapat diterima responden dengan baik. Dari hasil penelitian dapat diketahui bahwa buku saku efektif untuk meningkatkan pengetahuan responden. Destry Arlina Putri1, Sri Sunaringsih Ika Wardojo,Indah Dwi Pratiwi di Puskesmas Janti dan Mulyorejo, Malang, Jawa Timur.Tahun 2015.

\section{Kesimpulan}

Ibu- Ibu senang dengna model edukasi yang komprehensif seperti ceramah interaktif, diberikan buku saku, dan praktik simulasi dengan memvisualisasikan gambar pencegahan penularan TBC secara berkelompok sehingga keluar ide menggabar yang bagus.

1. Wanita Usia Subur dan akhirnya wanita Lanjut usia Juga Ikut serta.

2. Edukasi dengan ceramah, tanya jawab, pemberian hard copy draft buku saku dan simulasi tentang pencegahan penularan Tuberculosis mempunyai kontribusi terhadap peningkatan pengetahuan pencegahan penularan Tuberculosis pada Wanita Usia Subur dan Lanjut Usia di RPTRA Bambu Petung dan Payung Tunas Teratai.

\section{Daftar Pustaka}

[1] Kesehatan, P. D. (2015). Data Dan Informasi Tahun 2013 (Profil Kesehatan Indonesia).

[2] Demile, B., Zenebu, A., Shewaye, H., Xia, S., \& Guadie, A. (2018). Risk factors associated with multidrug-resistant tuberculosis (MDR-TB) in a tertiary armed force referral and teaching hospital, Ethiopia. BMC infectious diseases, 18(1), 249. 
[3] World Health Organization. Global Tuberculosis Report 2017 [Internet]. (2017). Geneva: WHO press.

Available from: http://www.who.int/tb/publications/global_report/gtbr2017_main_text.pdf

[4] Bisallah, C. I., Rampal, L., Lye, M. S., Sidik, S. M., Ibrahim, N., Iliyasu, Z., \& Onyilo, M. O. (2018). Effectiveness of health education intervention in improving knowledge, attitude, and practices regarding Tuberculosis among HIV patients in General Hospital Minna, Nigeria-A randomized control trial. PloS one, 13(2), e0192276.

[5] Maghfiroh, L., Pratama, A. N. W., \& Rachmawati, E. (2017). Pengaruh Pemberian Edukasi Menggunakan Buku Saku Bergambar dan Berbahasa Madura terhadap Tingkat Pengetahuan Penderita dan Pengawas Menelan Obat Tuberkulosis Paru (The Effect of A Pictorial Booklet with Madurese Language on Level of Knowledge among Tuber. Pustaka Kesehatan, 5(3), 420-424.

[6] Sukana, B., Herryanto, H., \& Supraptini, S. (2003). Pengaruh penyuluhan terhadap pengetahuan penderita tb paru di kabupaten tangerang. Jurnal Ekologi Kesehatan, 2(3 Des), 282-289.

[7] Ratnasari, D., \& Sakti, Y. B. H. (2015). Hubungan Antara Pendidikan Kesehatan Terhadap Perubahan Sikap dan Perilaku Penderita Tuberculosis yang Berobat di Wilayah Puskesmas Karanganyar. Psycho Idea, 13(2). 